\title{
STUDIES OF ENGLACIAL PROFILES IN THE LAKE HAZEN AREA OF NORTHERN ELLESMERE ISLAND
}

\author{
By G. HattersLey-Smtth \\ (Geophysics Section, Defence Research Board, Ottawa, Canada)
}

\begin{abstract}
Glaciological research on the ice cap to the north of Lake Hazen in northern Ellesmere Island was one of the main objectives of the Canadian I.G.Y. expedition to this area in 1957-1958. The method of nourishment of this ice cap and of Gilman Glacier, one of its southward-flowing outlets, was studied in pit and bore hole profiles above and below the equilibrium line, which was found at an elevation of about $1,200 \mathrm{~m}$. Between an elevation of about $\mathrm{I}, 450$ and $2,000 \mathrm{~m}$. accumulation is by firn formation, while between about 1,280 and $1,450 \mathrm{~m}$. interfingering of firn and superimposed ice occurs. At $\mathrm{I}, 800 \mathrm{~m}$. the mean annual accumulation over the past twenty years is estimated as $12.8 \mathrm{~g} . \mathrm{cm}^{-2}$. On Gilman Glacier below the equilibrium line variations in density and crystal structure in an ice core to a depth of $25 \mathrm{~m}$. are seen to depend on the proportion of firn to superimposed ice formed during accumulation. These variations correspond to past changes in the position of the equilibrium line. Englacial temperature measurements indicate a mean annual temperature of about $-18.5^{\circ} \mathrm{C}$. at an elevation of $1,040 \mathrm{~m}$. A budget deficit for Gilman Glacier during two years of observations may be related to the increased summer melting of the last 20 years, deduced from pit studies at $\mathrm{r}, 800 \mathrm{~m}$.
\end{abstract}

Résumé. L'expédition canadienne entreprise pendant l'Année Géophysique Internationale, 1957-1958, au lac Hazen, situé dans l'Île d'Ellesmere, a eu comme but principal la poursuite de recherches glaciologiques sur la calotte de glace au nord de ce lac. On a etudié l'alimentation de la calotte de glace et du glacier Gilman, lequel fournit un des débouchés de cette calotte vers le sud. On a pris des profils par des forages et par des carottes prélevées en amont et en aval de la ligne d'équilibre, qui se situe vers $1200 \mathrm{~m}$. Entre $1450 \mathrm{~m}$ et $2000 \mathrm{~m}$ environ l'alimentation se fait par la formation de névé, tandis qu'entre $1280 \mathrm{~m}$ et $1450 \mathrm{~m}$ il se produit une interfoliation de névé et de glace superposée. L'alimentation moyenne annuelle à r $800 \mathrm{~m}$ pendant les vingt dernières années est évaluée à $12,8 \mathrm{~g} \mathrm{~cm}^{-2}$. En aval de la ligne d'équilibre du glacier Gilman, on a trouvé que les variations de la densité de la glace, ainsi que la structure cristalline d'une carotte forée jusqu'à $25 \mathrm{~m}$ de profondeur, sont commandées par le rapport entre la quantité de névé et la quantité de glace superposée pendant l'alimentation. Ces variations correspondent aux changements produits antérieurement dans la localisation de la ligne d'équilibre. Des mesures de la température de la glace ont permis de calculer la température annuelle moyenne: environ $-18,5^{\circ} \mathrm{C}$ à une altitude de $1040 \mathrm{~m}$. Le bilan négatif pour le glacier Gilman pendant les deux années des observations s'explique peut-être par l'accroissement de la fusion estivale qui se manifeste depuis vingt ans et qu'on a constaté en effectuant des forages à $1800 \mathrm{~m}$.

Zusammenfassung. Die Gletscherforschung auf der Eiskappe nördlich von Lake Hazen war eine der Hauptzwecke der kanadischen I.G.J. Forschungsreise im Jahre 1957 und 1958. Die Ernährungsmethode dieser Eiskappe und des Gilman Glacier, eines ihrer südlichen Abflüsse wurde oberhalb und unterhalb der Gleitgewichtslinie, die bei einer Höhenlage von etwa $1200 \mathrm{~m}$ gefunden wurde, durch Profile in Schächten und Bohrlöchern studiert. In der Höhe zwischen 1450 und $2000 \mathrm{~m}$ erfolgt die Ernährung durch Firnbildung, während in Ḧ̈hen zwischen 1280 und $1450 \mathrm{~m}$ Firn und überlagertes Eis vermischt auftreten. Bei $1800 \mathrm{~m}$ Höhe ist die jährliche Akkumulation in den letzten 20 Jahren auf durchschnittlich $12,8 \mathrm{~g} \mathrm{~cm}^{-2} \mathrm{geschätzt}$ worden. Man sieht, dass auf dem Gilman Glacier, unterhalb der Gleichgewichtslinie, Verschiedenheiten der Dichte und Kristallstruktur in einem Eiskern bis zur Tiefe von $25 \mathrm{~m}$ abhängig sind vom Verhältnis zwischen Firn und überlagertes Eis, welches während des Akkumulationsprozesses gebildet wurde. Diese Verschiedenheiten entsprechen früheren Veränderungen in der Lage der Gleichgewichtslinie. Temperaturmessungen im Innern des Gletschers ergeben eine jährliche Durchschnittstemperatur von etwa $-18,5^{\circ} \mathrm{C}$ in einer Höhe von $1040 \mathrm{~m}$. Das Haushaltsdefizit des Gilman Glacier, während der Beobachtungen in den zwei Jahren, kann wahrscheinlich den sommerlichen Abschmelzung der letzten 20 Jahre zugeschrieben werden, was durch Untersuchungen in Schneeschächten in $1800 \mathrm{~m}$ Höhe abgeleitet wurde.

\section{INTRODUCTION}

The work described in this paper was carried out as part of the glaciological programme on Operation "Hazen", the Canadian I.G.Y. expedition to the Lake Hazen area of northern Ellesmere Island, 1957-58, organized by the Defence Research Board. Before 1957, two members of an advanced sledge party of the Oxford University Ellesmere Land Expedition, 1934-35, had been the only visitors to the ice cap north of Lake Hazen. ${ }^{\mathrm{I}}$ The present work was carried out on the central part of the ice cap and on Gilman Glacier, one of the southwardflowing outlet glaciers, where a camp was established $35 \mathrm{~km}$. north of Lake Hazen (Fig. I, p. 6I 5).

Rather more than half of northern Ellesmere Island is covered by ice at the present time. The highest part of the ice cap lies at an elevation between 1,800 and 2,000 m.; its surface is 


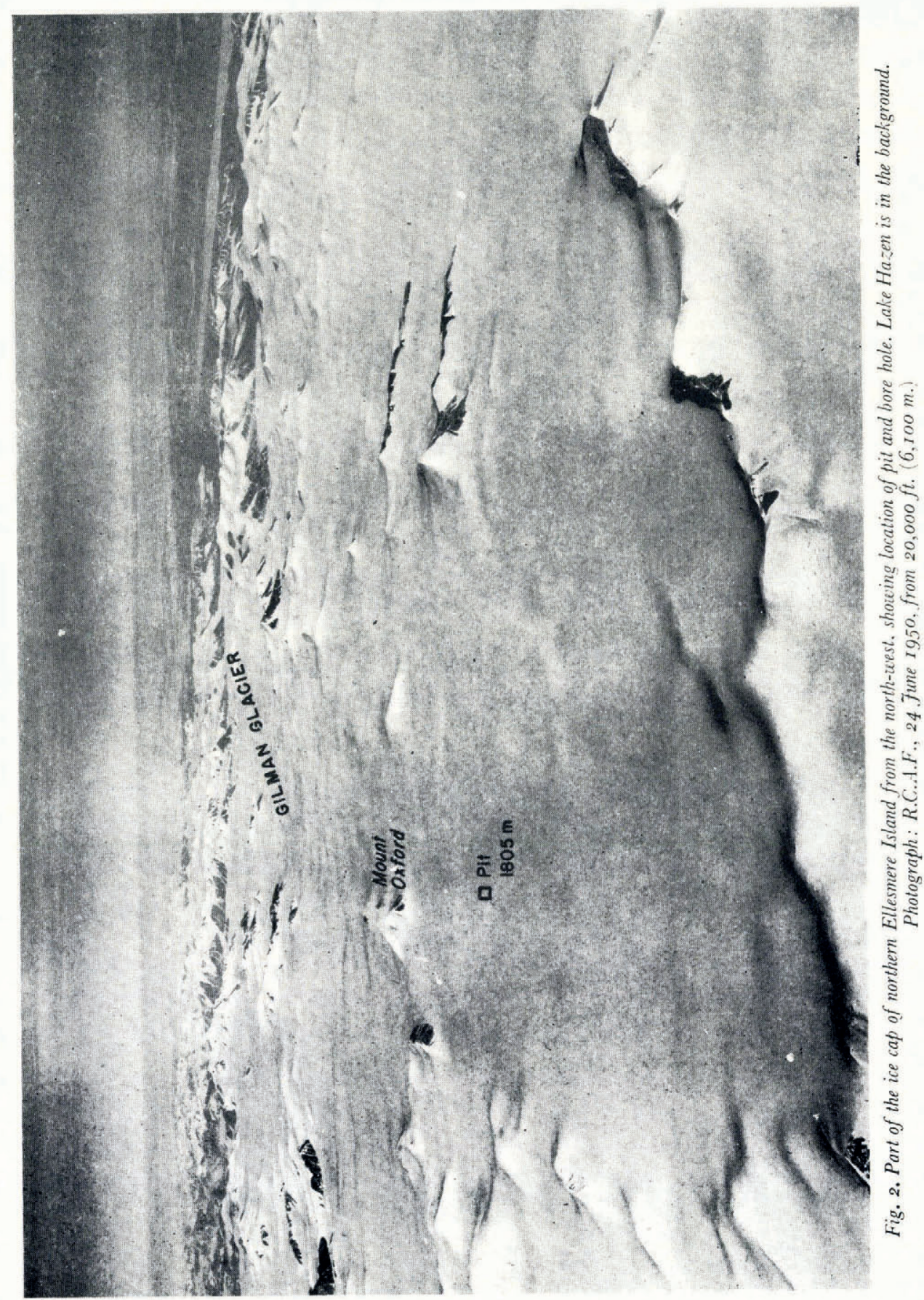




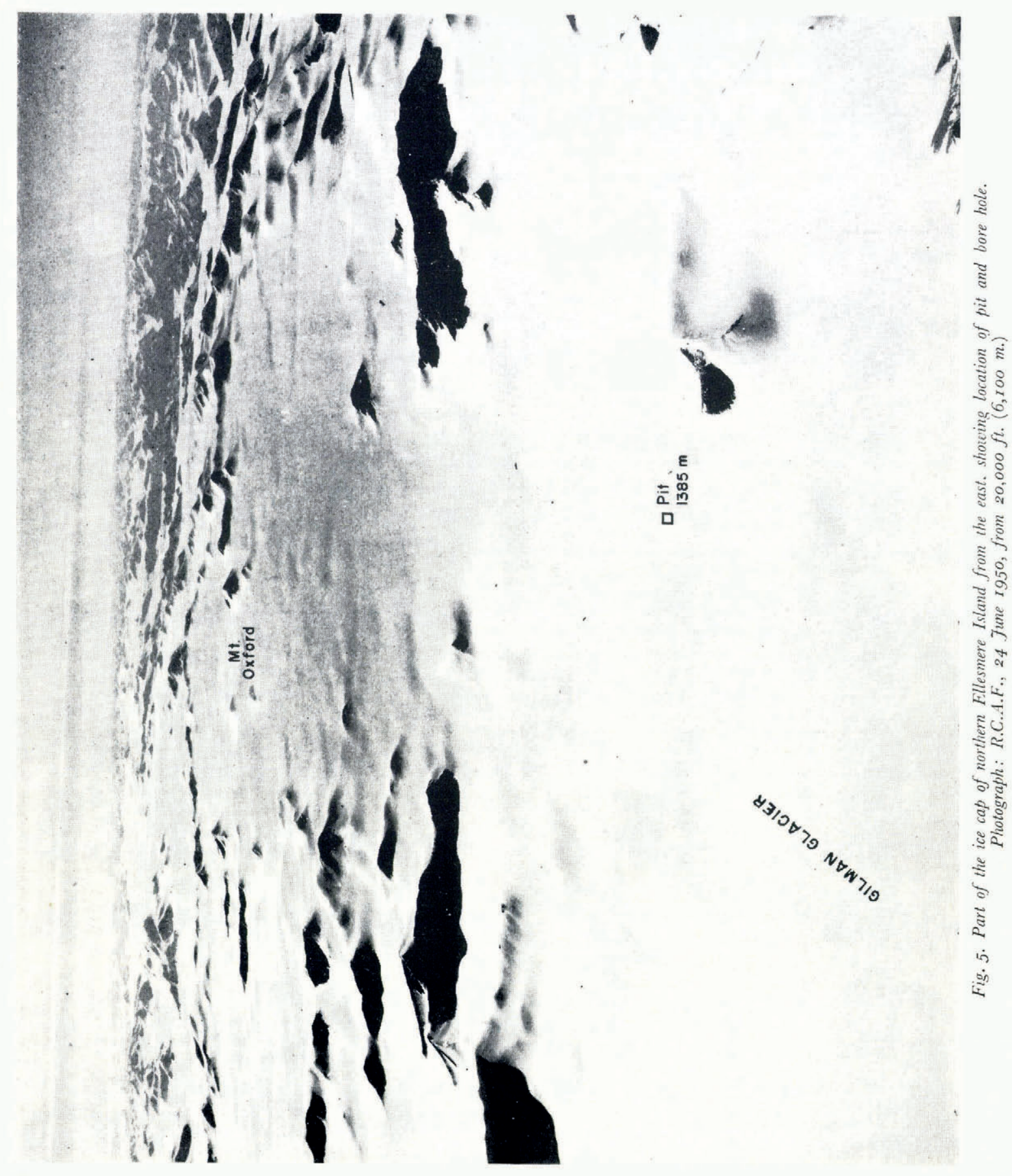




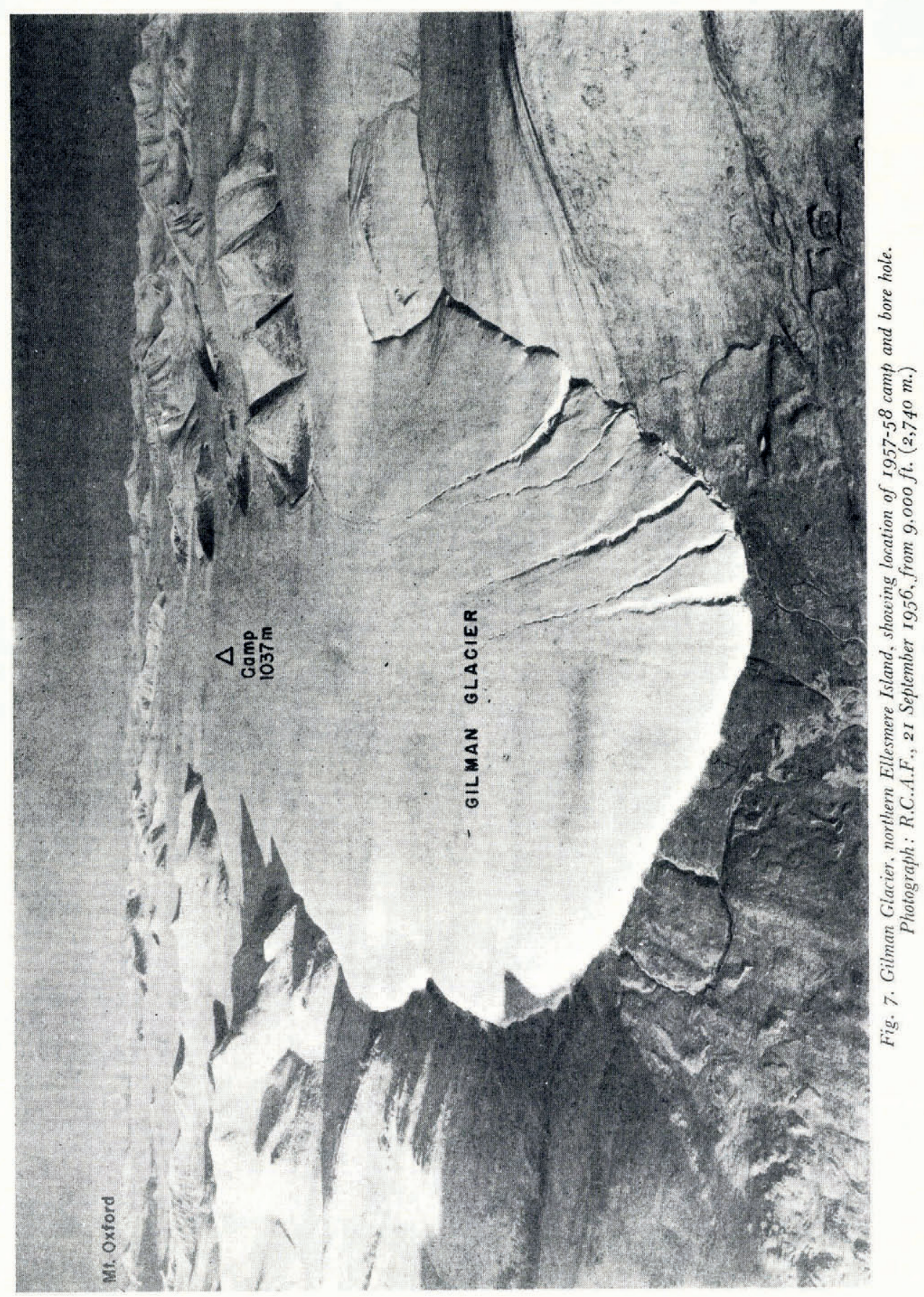


broken by nunataks, few of which rise above $2,000 \mathrm{~m}$. The highest mountains, one of which reaches a height of about $2,500 \mathrm{~m}$., are situated to the north and south. The top of the ice cap is by no means level, but shows an undulating hill and dale topography with a local relief of about $100 \mathrm{~m}$. To the north, the glaciers occupy valleys which extend far back into the mountains and which were presumably carved by rivers in pre-glacial time. To the south, the glaciers flow away much less steeply than to the north and are probably slower-moving.

One of the more interesting features of this ice cap is its method of nourishment, which can best be illustrated by reference to englacial profiles and temperature conditions in pits and bore holes at selected sites. First, firn accumulation at the highest level on the ice cap will be discussed; then the accumulation processes which operate near the equilibrium line* will be described; and, finally, the ice in a bore-hole on the Gilman Glacier below the equilibrium line will be studied with reference to the accumulation processes observed at higher levels. Englacial temperatures on the Gilman Glacier are given to show that it is one of the coldest valley glaciers in the Arctic to have received study.

\section{Firn Accumulation}

The site chosen for a deep pit was located at an elevation of r,805 m., $4 \mathrm{~km}$. west of Mount Oxford near the centre of an extensive névé, which is more or less level over an area of about $80 \mathrm{~km} .{ }^{2}$. To the north and west the névé is bounded by lines of nunataks rising to 2,000 m.; to the east by a buried rock ridge running south from Mount Oxford (Fig. 2, p. 612). The névé is drained by one of the main tributary glaciers on the east side of the Henrietta Nesmith Glacier.

The pit was dug with ice-pick and shovel to a depth of $6.5 \mathrm{~m}$. between I and 3 July I $95^{8}$; below a depth of $3 \mathrm{~m}$. it was necessary to clear the debris in a box which was lowered and raised by hand. From the bottom of the pit a S.I.P.R.E. 3 -inch $(7 \cdot 6-\mathrm{cm}$.) ice auger was used to bore a hole for a further $7 \mathrm{~m}$. Core recovery was almost complete. At intervals of $10 \mathrm{~cm}$. in the walls of the pit, samples of firn were collected in S.I.P.R.E.-type tubes for density determinations. The diameter of these tubes was $6 \mathrm{~cm}$. and the volume $500 \mathrm{~cm} .{ }^{3}$. Longer tubes of the same volume, but with a diameter of $4 \mathrm{~cm}$., gave poor results as they crushed and compacted the firn during insertion. In the bore hole densities were measured by weighing 5 or $10 \mathrm{~cm}$. lengths of the firn core (Fig. 3). The interpretation of the annual layering presented difficulties owing to the very low annual precipitation-only about $12 \mathrm{~g} . \mathrm{cm}^{-2}$ in $1957-5^{8}$; in consequence, seasonal layers were hard to identify.

At this altitude during the summer, the air temperature may rise to freezing point, or a little above, from the last week in June to the third week in July. Firn temperatures were measured in the walls of the $6.5 \mathrm{~m}$. pit with dial thermometers to an accuracy of $\pm 0.25^{\circ} \mathrm{C}$. during the digging of the pit (Fig. 4); the temperature in the bore-hole was measured to an accuracy of $\pm 0 \cdot 1^{\circ} \mathrm{C}$. by means of a standard alcohol thermometer, which was insulated and lowered to the bottom. Temperatures in the snow and firn fell very rapidly from close to freezing point in the top $20 \mathrm{~cm}$. to about $-2^{\circ} \mathrm{C}$. at a depth of $30 \mathrm{~cm}$., and to about $-25^{\circ} \mathrm{C}$. at a depth of $5 \mathrm{~m}$. Below this depth seasonal variations in temperature of the firn are small. The temperature near the bottom of the bore-hole at $12.45 \mathrm{~m}$. was $-24 \cdot 2^{\circ} \mathrm{C}$., which must be close to the mean annual temperature at this altitude. Snow temperatures were measured again on 5 August when, in a pit $3 \mathrm{~km}$. away at a slightly lower altitude, the surface snow temperature was $-9 \cdot 2^{\circ} \mathrm{C}$., the temperature at a depth of $20 \mathrm{~cm} .-7 \cdot \mathrm{I}^{\circ} \mathrm{C}$., and at a depth of $40 \mathrm{~cm} .-8 \cdot 0^{\circ} \mathrm{C}$.

It is concluded from the above that zero temperatures in the summer are most unlikely to penetrate below a depth of $30-40 \mathrm{~cm}$. from the surface, or below the winter snow-pack. In other words, melt water percolating from the surface will not normally freeze within the firn

* The term "equilibrium line" is used to denote the line where the accumulation of superimposed ice is equal to the ablation. See P. D. Baird, Journal of Glaciology, Vol. 2, No. 11, 1952, p. 8. Ed. 
PROFILES IN THE LAKE HAZEN AREA
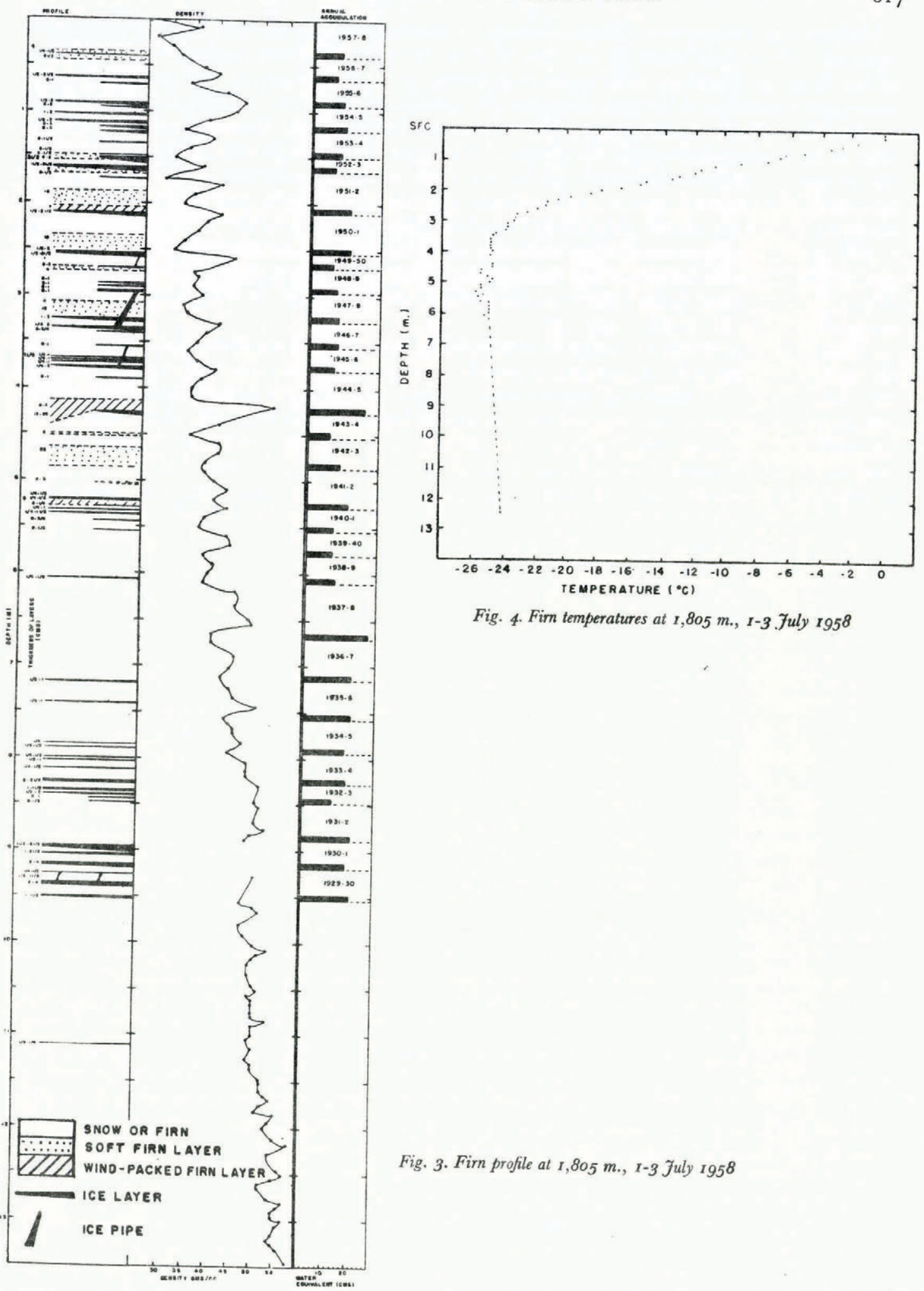

Fig. 4. Firn temperatures at 1,805 m., $1-3$. Fuly 1958

Fig. 3. Firn profile at 1,805 m., $x-3$ July 1958 
of the previous budget year. This conclusion is substantiated by the fact that ice pipes were observed only in four layers in the pit and that the longest of these penetrated only $40 \mathrm{~cm}$. of firn (Fig. 3). However, melt water may freeze to form ice layers at any level within the snow-pack according to the prevailing thermal gradient. Thus, each ice layer is not an annual marker, for a single annual deposit may contain several ice layers. Nevertheless, it is believed that, as on Isachsen's Plateau, Spitsbergen, ${ }^{2}$ the major ice layers are annual markers. But on the ice cap of northern Ellesmere Island the major ice layers may not always occur at the boundary between one year's accumulation and the next year's, and from some annual strata ice layers are absent altogether. Between major ice layers in the $6 \cdot 5-\mathrm{m}$. pit and in a $\mathrm{I} \cdot 4-\mathrm{m}$. pit dug $5 \mathrm{~km}$. away on the south side of Mount Oxford, reasonably good correlation was obtained to the bottom of the stratum shown as the $1954-55$ deposit in the $6 \cdot 5-\mathrm{m}$. pit (Fig. 3); the ice layer at the bottom of this stratum was at $1 \cdot 20 \mathrm{~m}$. in the $6 \cdot 5-\mathrm{m}$. pit, while it occurred at $\mathrm{I} \cdot 33 \mathrm{~m}$. in the $\mathrm{I} \cdot 4$ - $\mathrm{m}$. pit.

The formation of the ice layers is visualized as follows: in a summer when the whole of the snow-pack rises to a temperature of zero C., a major ice layer may form at the bottom of the snow-pack on the surface of the previous summer's icy crust. ${ }^{2,3}$ It is believed that on the highest part of the ice cap of northern Ellesmere Island this only occurs when there is an unusually low snow accumulation or an unusually warm summer. If the whole of the snowpack has not been warmed to zero, percolating melt water is likely to freeze to form ice layers at intermediate levels - often where thin wind crusts occur in the snow. Such ice layers undoubtedly form in the present location, but it is believed that the bulk of the melt water freezes to form a major ice layer quite close to the surface of the snow-pack because of the very low near-surface temperatures. Furthermore, if this were not so, and if much percolation of water through the snow-pack were usual, there would be less striking variations in density than were measured in the upper part of the pit (Fig. 3). Ice pipes were considered to have their upper ends near the summer surface and not to extend through more than one annual stratum.

Conditions on a temperate or sub-polar glacier, where the summer temperature of the firn is zero throughout or for a considerable depth, are very different, and ice layers may form far below the snow-pack. On Upper Seward Glacier, Yukon Territory, Sharp observed that major ice layers seldom occurred near the top of an annual deposit, ${ }^{4}$ but he was able to use dirt layers of wind-blown dust as markers between one year's deposit and the next. 5 He states that other methods of recognizing annual stratification proved inapplicable. Ahlmann ${ }^{2}$ found dirty boundary-layers in the firn on Isachsen's Plateau, Spitsbergen. On the other hand, Baird and Ward ${ }^{6}$ were unable to recognize an annual stratification in the firn on the Penny Ice Cap of southern Baffin Island. In dating the annual layers in the present pit, no help was available from dirt layers associated with autumn ice crusts. The nearest exposed rock was $5 \mathrm{~km}$. away on nunataks, parts of which are snow-free throughout the year. While there are probably dirt particles scattered through the firn, there is insufficient melting at the surface to concentrate the dirt into visible layers; at least no such layers were observed in the pit.

In the pit walls the position and thickness of the layers of clear bluish ice were plotted (Fig. 3). The continuous layers, visible in each of the four walls of the pit and usually thicker than the incomplete layers, are conventionally shown extending right across the section; the partial layers are shown extending half-way across the section. The site of the pit was revisited on 5 August, but the pit was not visible as it had been covered over by drifted snow. A shallow pit nearby showed $15-20 \mathrm{~cm}$. of wind-packed snow resting on a $\mathrm{I}-\mathrm{cm}$. ice layer; the windpacked snow was believed to have been mainly deposited during a blizzard on 21 July. No other ice layers were observed in the snow-pack, but $5 \mathrm{~cm}$. below the ice layer there was a 5 -cm. layer of recrystallized and partly refrozen snow, which was harder than the layers above or below. This layer was thought to indicate the maximum depth of melt water penetration in the 1958 summer. The ice layer was considered to be a true summer surface, and the 
blizzard of 2 I July was regarded as marking the end of the summer melt and the end of the budget year. For convenience the annual deposits in the pit may be considered to have accumulated between I August and 31 July in any budget year.

In order to separate annual strata in the firn, density changes and the presence of recognizably harder and softer firn layers were used to supplement deductions from the presence of ice layers. In the walls of the pit, layers of soft, often loose, firn of relatively low density were considered to be late summer or autumn layers. These layers, which had a few grains up to $5 \mathrm{~mm}$., were more coarsely granular than the denser winter layers with grains which averaged I to $2 \mathrm{~mm}$. Not every late summer and autumn layer is necessarily of low density, because some of these layers may have become denser and harder through refreezing of percolating melt water. Several unusually hard layers of firn, derived from wind-packed snow, were observed in the section; one of these, at a depth of $4.2 \mathrm{~m}$., varied in thickness from 13 to $26 \mathrm{~cm}$. and had a density of $0.53 \mathrm{~g} . \mathrm{cm}^{-3}$, although the densities of the firn immediately above and below it were 0.35 and $0.4 \mathrm{I}$ g. $\mathrm{cm} .^{-3}$ respectively. Three out of the four layers of hard, originally wind-packed snow observed in the pit were interpreted, from their contiguity to ice layers, as definitely of late summer or autumn formation. Their homogeneity indicated that each was the result of a single blizzard.

The soft low-density firn, derived from late summer or autumn snow, may occur above or below an ice layer, but, where there is no ice layer or crust, the placing of the boundary between annual layers within the low-density firn is necessarily arbitrary. It was found that the majority of low points in the density curve in the upper $5.5 \mathrm{~m}$. of the pit occurred just above major ice layers (Fig. 3). This substantiates the idea that the low-density layers are of late summer or autumn origin, and also suggests that the major ice layers are usually formed near the surface and not by melt water percolating the snow-pack to the previous summer's ice crust. But where the firn immediately above an ice layer is of relatively high density it may in part have absorbed percolating melt water.

The stratigraphic section (Fig. 3) must be viewed with these difficulties and limitations of interpretation in mind, but the writer believes that the interpretation is correct to within one or two years over the last twenty years. In the annual deposits of the nine years before the $1938-39$ stratum there were fewer ice layers to serve as markers, and the stratigraphy is more likely to be at fault than in the upper part of the section. From the thickness and mean density of annual firn deposits and from the average thickness of ice layers, of assumed density $0 \cdot 90$, the water equivalent of each year's net accumulation has been computed (Fig. 3).

The mean annual accumulation for the twenty years from 1938 to 1958 amounts to 12.8 g. $\mathrm{cm}^{-2}$. For comparison Fristrup 7 states that the annual accumulation in $1948-49$ on Chr. Erichsen Brae in Peary Land was I $\cdot 4 \mathrm{~cm}$. If the interpretation below the $193^{8} \mathrm{stratum}$ is roughly correct, a higher mean annual accumulation is indicated for the years $1929-38$; the figures are $18.9 \mathrm{~g}$. $\mathrm{cm}^{-2}$. If the mean annual accumulation was in fact higher during this period, the possibility that it was due to local drifting rather than to a change in precipitation cannot be excluded. It may be noted that Diamond ${ }^{8}$ has deduced a lower precipitation on the ice cap of northern Greenland during the last twenty-five years, and points out that this has been accompanied by an apparent increase in the temperatures of northern Greenland.

In the lower 4 metres of the section no annual interpretation was attempted in the firn, which was considered to have been deposited before the year i929-30. At these depths compaction and settling produced a firn of density from 0.47 to $0.58 \mathrm{~g} . \mathrm{cm}$. $^{-3}$, with a mean density of about $0.52 \mathrm{~g}$. $\mathrm{cm}^{-3}$; the grain size was consistently $1-2 \mathrm{~mm}$. In this firn any seasonal variations in density were much less apparent than in the upper part of the section, particularly between depths of $I 0.25$ and II.25 m. Furthermore, there were no ice layers, except a very thin layer at I I. I m., representing a summer surface. Low density values at 9.8 and $10.25 \mathrm{~m}$. and at fairly regular intervals from I I $8 \mathrm{~m}$. to the bottom of the bore hole might well represent layers of summer snow and hence annual boundary layers, but it is impossible to be certain, 
because critical layers may have been missed in the density determinations. Interpretation would have been easier if it had been possible to take more closely-spaced samples of firn for density determinations. On the basis of annual water equivalents determined in the upper part of the section, the bore hole section below the I929 summer horizon should represent I I-I 6 years of accumulation. If so, the bottom of the bore-hole corresponds to a year $1916 \pm 3$.

On the assumption that the above chronology is roughly correct, the almost complete absence of ice layers below $9.5 \mathrm{~m}$. means that there was virtually no melting in the summers for a period of at least a decade before 1929. In subsequent years there was apparently not much melting in the summers from about 1934 to 1940 . The years since 1940 were marked by appreciable melting. However, it must be remembered that above a depth of $6.5 \mathrm{~m}$. the stratification was observed in a pit about $4 \mathrm{~m}^{2}$ in area at the top and stepped down to about I $\mathrm{m}^{2}$ at the bottom, whereas below a depth of $6 \cdot 5 \mathrm{~m}$. the stratification was observed in a firn core $7.6 \mathrm{~cm}$. in diameter. Thus, the ice layers above the $6.5 \mathrm{~m}$. depth may have been given an undue emphasis in the profile (Fig. 3).

\section{Accumulation near the Equilibrium Line}

The mean elevation of the equilibrium line is about $1,200 \mathrm{~m}$. There was a small accumulation of superimposed ice at this elevation in 1958 , although in the warmer summer of 1957 no accumulation took place below an elevation of about $1,250 \mathrm{~m}$. In Peary Land, Fristrup 7 observed what he termed the "snow line" at an elevation of I, IOO-I,300 m. in the eastern and southern regions, and at a rather lower elevation in the western region.

For study of the accumulation near the equilibrium line shallow pits were dug at an elevation of $1,384 \mathrm{~m}$. near the middle of the upper part of the Gilman Glacier, which is about $7 \mathrm{~km}$. wide (Fig. 5, p. 6r3). The pits were dug on 5 July 1958, near the beginning of the melt season, and on 7 August after the melt season had ended at this elevation. A bore hole was drilled to a depth of $3 \mathrm{~m}$. from the bottom of the 7 August pit. Temperatures, densities, and profile are shown in Fig. 6. Below the snow the profile shows layers of fine- and coarsegrained icy firn, alternating with layers of milky, air-rich ice and layers of relatively clear, bluish ice. Observations at a stake close to the pit in 1957 and $195^{8}$ gave the annual accumulations for $1956-57$ and $1957-58$, which were respectively $7 \cdot 0$ and $10.2 \mathrm{~g} . \mathrm{cm} .^{-2}$. It was not possible to assess the annual stratification before 1956-57. Observations indicated that layers of superimposed ice are formed by water draining down through the firn and refreezing at the bottom of the snow-pack. In some years melting will be complete or nearly so, and refreezing will give a layer of mainly clear, bluish ice; in other years melting will be partial and layers of milky, air-rich ice are formed by refreezing. When there is only moderate melting, layers of more or less icy firn are produced with or without a layer of ice at the bottom. It is safe to say that the layers of firn seen in the profiles are the accumulation of one year, which may also have included formation of an ice layer. The thicker layers of ice shown in the profile presumably represent accumulation of several years, but here it was impossible to separate the annual deposits.

From his observations in the Thule ramp area of northern Greenland, Schytt 3 has suggested that the superimposed ice "grows bubbly" (milky) during late spring and early summer as the first melt water percolates the cold winter snow. Later in the summer, as the snow becomes saturated with melt water, the refrozen ice holds less air and is mainly clear in appearance. He suggests that it might be possible to work out an annual stratification by recognition of these seasonal layers. It is not apparent how such a method could be applied to the present profile with the data available, but, if Schytt's hypothesis is correct, the boundaries between milky and clear ice should not be interpreted as annual markers.

Profile on Gilman Glacier below the Equilibrium Line

At the Gilman Glacier camp at an elevation of 1,037 m. (Fig. 7, p. 61 4), a hole was bored to a depth of $24.5 \mathrm{~m}$. in May 1958. Core recovery was almost complete. Density determina- 


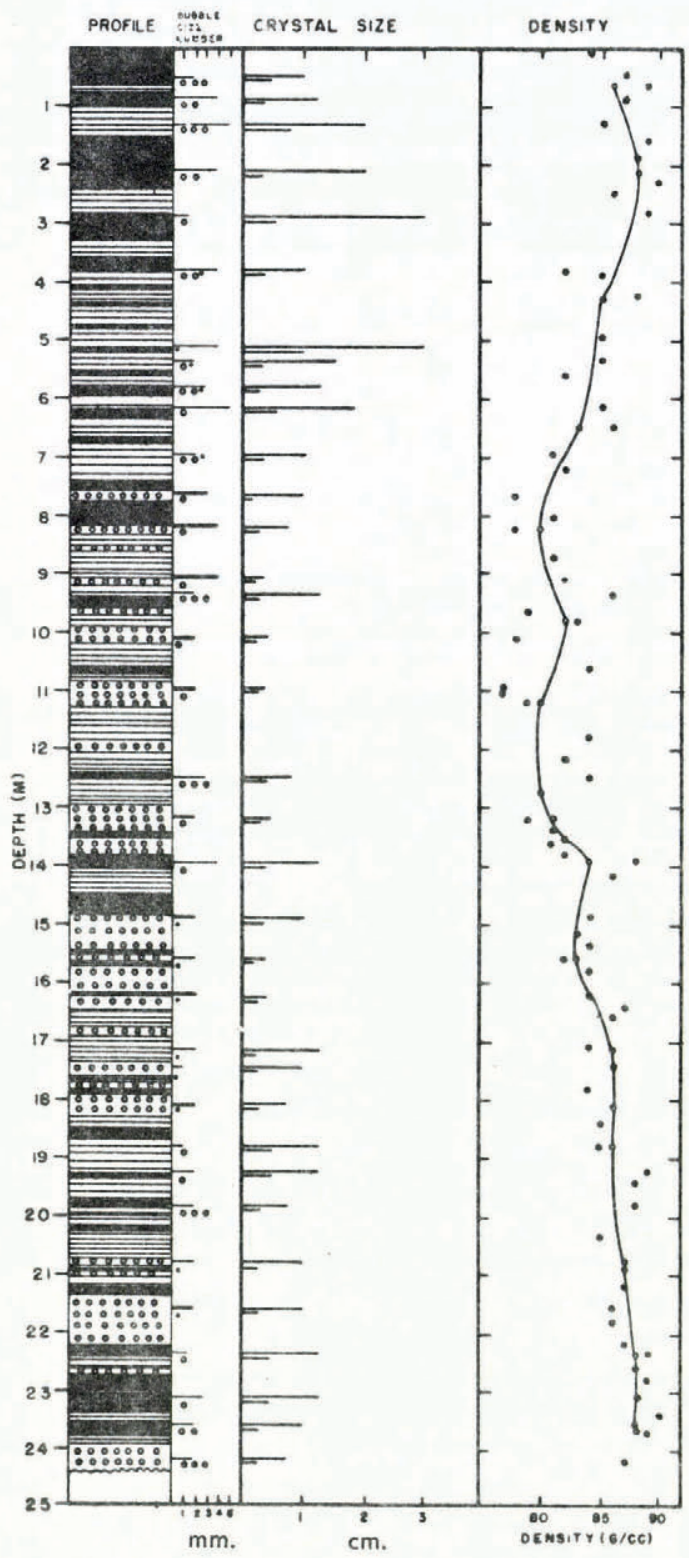

PROFILE

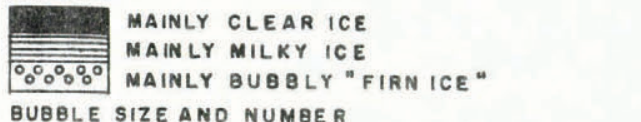

BUBBLE SIZE ANO NUMBER

MAXM. DIAM. IN THIN SECTION

(HEAVY LINE $>10 / \mathrm{CM}^{2}$ OF DIAM. $>0.5 \mathrm{MM}$.)

(iㅜ)( $: 5$ ) NUMBER OF BUBBLES $<0.6 \mathrm{MM}$. IN DIAM.

CRYSTAL SIZE

MAXM. DIAM. ? IN THIN SECTION

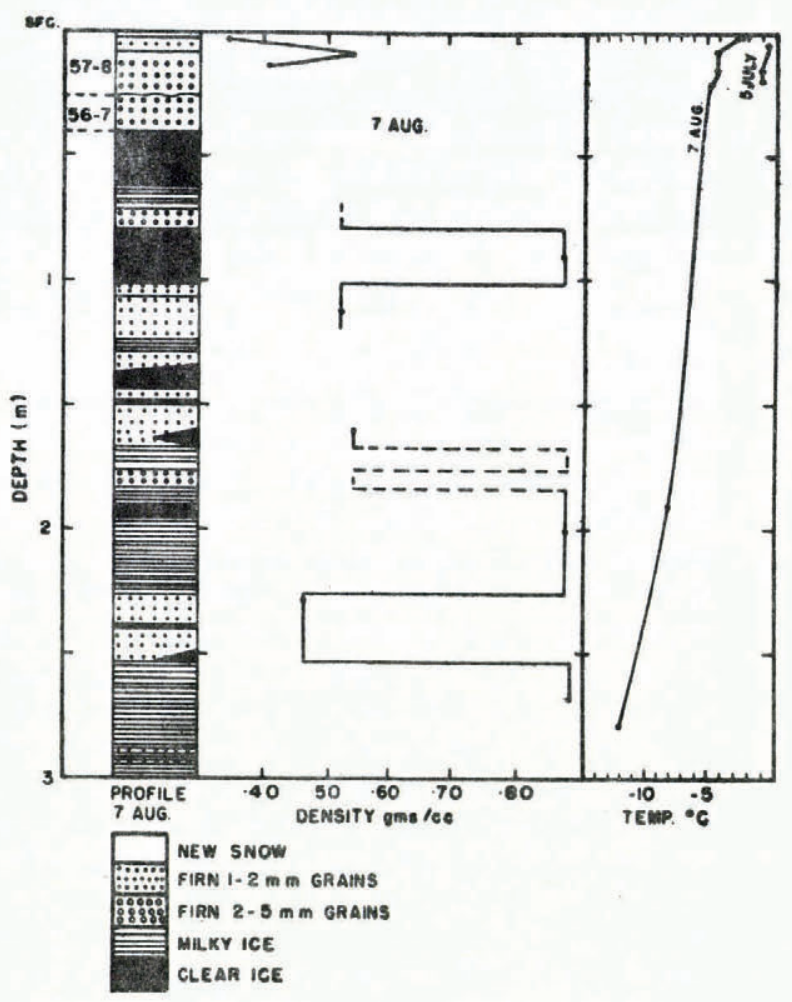

Fig. 6. Englacial measurements at $1,3^{8} 4 \mathrm{~m}$., $195^{8}$

Fig. 8. Englacial studies on Gilman Glacier, May 1958 In column 2 the thick line indicates more than 10 bubbles above $0.5 \mathrm{~mm}$. diameter per $\mathrm{cm}$. in the thin section examined. $\cdot=5$ bubbles below $0.5 \mathrm{~mm}$. diameter, $O=I O$ bubbles, $O^{*}=I_{5}$ bubbles, $o o=20$ bubbles, $00 \cdot=25$ bubbles, $000=30$ bubbles. 
tions were made in the recovered core by weighing measured (usually ro $\mathrm{cm}$.) lengths of core. The error in density is believed not to exceed $\pm 0.02 \mathrm{~g} . \mathrm{cm} \cdot{ }^{-3}$, and in most cases is probably less. Samples were taken at selected depths, from which thin sections in the horizontal plane were melted down to an average thickness of $\mathrm{I} \mathrm{mm}$. The thin sections were viewed through crossed polaroid plates; the texture was noted and approximate measurements were made of crystal size and of bubble size and frequency (Fig. 8).

In the upper $7.5 \mathrm{~m}$. of the core, the mean density of the ice was $0.86 \mathrm{~g} . \mathrm{cm}^{-3}$, with values ranging from $0.8 \mathrm{I}$ to 0.9 ; from a depth of $7.5 \mathrm{~m}$. to a depth of $18.25 \mathrm{~m}$. the mean density was 0.82 g. $\mathrm{cm}^{-3}$, with values ranging from 0.77 to 0.88 ; from 18.25 to $24.5 \mathrm{~m}$. the mean density increased to $0.87 \mathrm{~g}$. $\mathrm{cm}^{-3}$, with values ranging from 0.85 to 0.9 . These density changes were related to the crystal size and texture, and to the number and size of the bubbles observed in thin sections. The ice was roughly classified into three types, which result from the accumulation processes observed near the equilibrium line. The relatively clear, bluish ice in both profiles and the milky, air-rich ice in both profiles are each considered to have been deposited under similar conditions. The clear ice tended to have a more inequigranular texture with the crystals averaging $4 \mathrm{~mm}$. and some as large as $3 \mathrm{~cm}$. in diameter, and relatively fewer bubbles than the milky ice. Considerable intergrowth of crystals was noted in both types. Some sections of the clear ice showed needle-like, vertically orientated bubbles as in lake ice. The third type, a lower density ice provisionally called "firn ice", resulted from normal firn accumulation; in thin section it was mainly polygonal in texture and very bubbly. The crystals were smaller, averaging $2 \mathrm{~mm}$. with some up to $5 \mathrm{~mm}$. in diameter, and were more equigranular and less intergrown than in the other two types; larger and more numerous bubbles were present. The lower densities at depths of $7 \cdot 5$ to $18.25 \mathrm{~m}$. represent a predominant accumulation of this "firn ice". Most of the densities measured in the "firn ice" are appropriate to firn, for the minimum density for ice is usually regarded as $0 \cdot 83$ to $0 \cdot 84 \mathrm{~g} . \mathrm{cm} .^{-3}$. Although the "firn ice" contained a high bubble concentration and two adjacent bubbles were often joined together, in general the bubbles did not appear to be intercommunicating. The majority were about $\mathrm{I} \mathrm{mm}$. in diameter and the separation between bubbles was usually not less than $2 \mathrm{~mm}$. The writer was definitely of the opinion that the material was impermeable ice, and not high-grade firn. Nevertheless, the situation is similar to that described by Schytt 3 in the ablation area at the margin of the Greenland ice cap near Thule, where air-rich firn layers are enclosed between thick layers of solid ice. It may be that thick layers of superimposed ice effectively seal off underlying layers of firn, which reach a condition of impermeability with a higher bubble or air content and lower density than is normal for "young" glacier ice. Furthermore, low englacial temperatures prevent water percolating the firn, and the escape of air bubbles. 9

The equilibrium line is situated about $160 \mathrm{~m}$. in elevation above the camp and $7.5 \mathrm{~km}$. up the glacier. The rate of surface movement of the glacier is about $25 \mathrm{~m}$. a year between the camp and the equilibrium line. ${ }^{10}$ The near-surface ice at the camp has therefore taken about 300 years to move down from the present area of accumulation. The mean ablation between the camp and the equilibrium line is of the order of $20 \mathrm{~cm}$. of ice a year. This means that the ice now at the surface near the camp would have been at a depth of $60 \mathrm{~m}$. when it was near the equilibrium line, if the position of the equilibrium line and the amount of ablation had not changed in the last 300 years. At the present rate of accumulation on the ice cap of about $12 \mathrm{~g}$. cm. ${ }^{-2}$, it would have taken 500 years for $60 \mathrm{~m}$. of ice to accumulate, so that the ice at the surface near the camp would have been at least 500 years old when it was near the equilibrium line. Its present age would therefore be of the order of 800 years. However, the low density makes it unlikely that the "firn ice" can be very old, and the inference is that the ablation is now greater or the accumulation less-or both-than when the ice was deposited. This means in effect that the equilibrium line has been appreciably raised since the "firn ice" was deposited. 
Since the bore hole was below the equilibrium line, there was a dirt layer at the surface representing an ablation period of unknown length. Light patches of fine dust were considered to have been deposited by occasional high winds, especially in the summer. They occurred at depths of $2 \cdot 5,4 \cdot 5,19 \cdot 5$ and $22.5 \mathrm{~m}$. The dust consisted of minute particles of quartz, banded

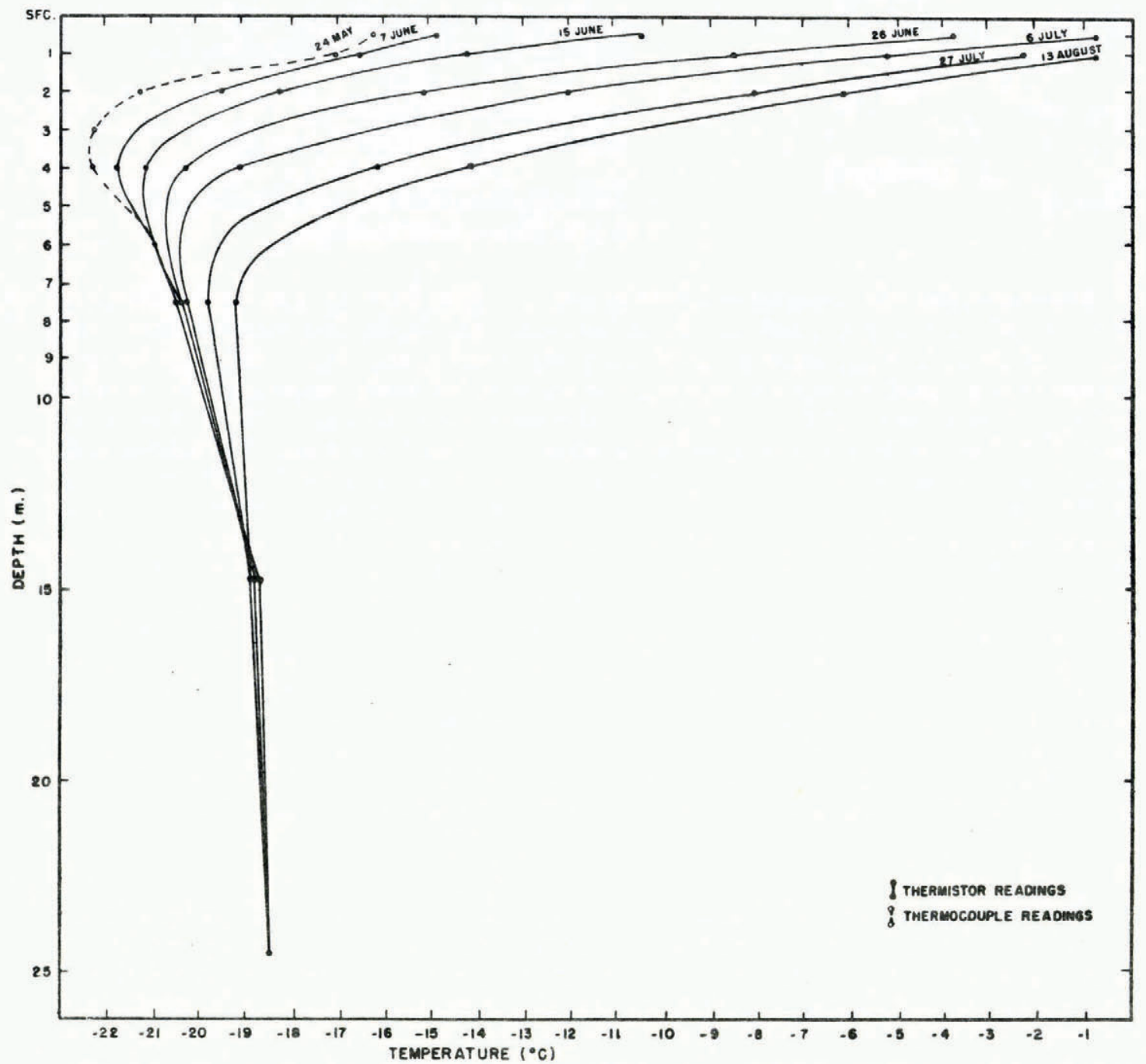

Fig. 9. Englacial temperatures at 1,037 m., Gilman Glacier, May-August 1958

calcite, jasper and flakes of chlorite-schist, up to $\mathrm{I} \cdot 25 \mathrm{~mm}$. in diameter, all of which were derived from the local Cape Rawson group of rocks. There were no heavy dirt layers in the core to indicate a significant break in deposition and a period of net ablation. The different ice types studied in the core displayed different weathering characteristics at the surface of the glacier in the summer, and probably also account for the banding in the terminal ice cliff.

Although it was impossible to deduce an annual stratification, the chronological sequence of events suggested by the ice core at the camp may be summarized as follows: 
Depth (m.)

Surface Equilibrium Line

At about $1,200 \mathrm{~m}$.

Raised

$0-7 \cdot 5$

$$
7 \cdot 5^{-18}
$$

Raised

\section{Lowered}

I $8-24 \cdot 5$

\section{Bore-hole Section}

Present net ablation and formation of surface dirt layer.

Below equilibrium line.

Accumulation of superimposed ice.

Close to, but just above, equilibrium line.

Accumulation of mainly firn.

Appreciably above equilibrium line.

Accumulation of mainly superimposed ice. A little above equilibrium line.

Thermocouples were installed at depths of $0.5, \mathrm{I}, 2,3,4,6$ and $24.5 \mathrm{~m}$., and thermistors at depths of $0.5,1,2,4,7.5$ and $14.7 \mathrm{~m}$. in bore holes; the depths were measured below the surface of the ice in May, when the snow cover was about $20 \mathrm{~cm}$. deep. Temperatures were recorded twice a week; curves of temperature versus depth for selected dates have been plotted in Fig. 9. After the end of May, except for the thermocouple at $24.5 \mathrm{~m}$., only the thermistors were read. From ro June onwards, the snow surface was gradually lowered by settling and melting, until by 29 June all the snow had melted. Ablation of ice proceeded until by 15 July the thermistor at a depth of $0.5 \mathrm{~m}$. had melted out. By I I August when the last thermistor readings were taken, $67 \mathrm{~cm}$. of ice had been lost from the surface by ablation, and the nominal depths of the thermistors were reduced by this amount. Increases in temperature at the shallower depths during the summer ranged from $-\mathrm{I} 5$ to $0^{\circ} \mathrm{C}$. at $0.5 \mathrm{~m}$., $-\mathrm{I} 6.5$ to $-\mathrm{I}^{\circ} \mathrm{C}$. at $\mathrm{I} \mathrm{m} .,-\mathrm{I} 9.5$ to $-6^{\circ} \mathrm{C}$. at $2 \mathrm{~m}$., -22 to $-\mathrm{I} 4^{\circ} \mathrm{C}$. at $4 \mathrm{~m}$., and -20.5 to $-\mathrm{I} 9.5^{\circ} \mathrm{C}$. at $7.5 \mathrm{~m}$. At $14.7 \mathrm{~m}$. the temperature remained constant at $-18 \cdot 8^{\circ} \mathrm{C}$. within an accuracy of $\pm .15^{\circ} \mathrm{C}$. (an apparent decrease in temperature of $0.2^{\circ} \mathrm{C}$. was due to experimental error); at $24.5 \mathrm{~m}$. it remained constant at $-\mathrm{I} 8 \cdot 4^{\circ} \mathrm{C}$. (within an accuracy of $\pm \cdot 25^{\circ} \mathrm{C}$.), which was the mean of all the thermocouple readings at this depth. The mean annual temperature at this altitude can therefore be assumed to be close to $-18 \cdot 4^{\circ} \mathrm{C}$. Fristrup reported similar thermal conditions in the upper layers of Chr. Erichsen Brae in Peary Land.7

\section{Conclusions}

The present paper describes the method of nourishment of the ice cap of northern Ellesmere Island. A further paper will deal with the budget of the Gilman Glacier and its accumulation region with a total area of about $430 \mathrm{~km} .{ }^{2}$. Observations in the summer of $195^{8}$ indicated a budget deficit of about 60 per cent for Gilman Glacier in $1957-5^{8} ;{ }^{\text {II }}$ it seems certain that the deficit was appreciably greater in the budget year 1956-57, for the winter accumulation was less and the summer warmer. ${ }^{12}$ The budget deficit in 1957-58 was equivalent to a deficiency of about $6 \mathrm{~g} . \mathrm{cm}^{-2}$ in the accumulation area, or an excess of mean ablation in the ablation area of about $27 \mathrm{~g} . \mathrm{cm} .^{-2}$.

At the present time the accumulation between an elevation of about $1,45^{\circ} \mathrm{m}$. and the highest part of the ice cap at 2,00o $\mathrm{m}$. is by firn formation; between an elevation of about $\mathrm{I}, 28 \mathrm{O}$ and $\mathrm{I}, 45 \mathrm{O} \mathrm{m}$. interfingering of firn and superimposed ice takes place. (In Peary Land, firn only occurs on the highest parts of Chr. Erichsen Brae near the 1, 300 m. level.7) Accumulation exclusively by formation of superimposed ice probably only occurs in a fairly narrow belt between the equilibrium line at about I,200 $\mathrm{m}$. and an elevation of about $\mathrm{I}, 28 \mathrm{o} \mathrm{m}$. This belt would be wider if the slope of the glacier were not fairly steep and consequently the drainage good near the equilibrium line, not far below which Gilman Glacier debouches from 
the ice cap into its valley. Appreciable changes in the position of the equilibrium line may have occurred within the last few hundred years.

Data from the highest part of the ice cap indicate somewhat warmer summers in the last 20 years, and an accumulation which may have been rather less than in the previous 9 years. It is probable, therefore, that Gilman Glacier was more nearly in a state of balance twenty years ago, and possible that the inferred climatic trends of the last twenty years are mainly responsible for the present budget deficit. The climatic warming, which is said to have reached its height in the North Atlantic area generally in the 1930's or 1940's, ${ }^{13}$ also appears to have affected northern Ellesmere Isłand.

\section{Acknowledgements}

Grateful acknowledgement is made to Mr. F. W. Simpson and Dr. G. W. Williams of the Defence Research Telecommunications Establishment for calibration of the thermistors and to Mr. P. R. Beadle of the Defence Research Northern Laboratory for calibration of the thermocouples; and to Messrs. K. C. Arnold, C. R. Harington, J. R. Lotz and R. B. Sagar of the Defence Research Board Operation "Hazen" for their valuable assistance in the field. This paper is published by permission of the Chairman, Defence Research Board of Canada.

MS. received I8 June 1959

\section{REFERENGES}

I. Moore, A. W. The sledge journey to Grant Land. Oxford University Ellesmere Land Expedition, III. Geographical Journal, Vol. 87, No. 5, 1936, p. 423-25.

2. Ahlmann, H. W. Scientific results of the Norwegian-Swedish Spitsbergen Expedition in 1934. Part I. The stratification of the snow and firn on Isachsen's Plateau. Geografiska Annaler, Årg. 1 7, 1935-36, p. 31-37.

3. Schytt, V. Glaciological investigations in the Thule ramp area. U.S. Snow, Ice and Permafrost Research Establishment. Research Report 28, 1955 , p. 30-42, 52-57.

4. Sharp, R. P. Accumulation on the Seward-Malaspina glacier system, Canada-Alaska. Bulletin of the Geological Society of America, Vol. 62, 1951, p. 729. 5. Sharp, R. P. Features of the firn on Upper Seward Glacier, St. Elias Mountains, Canada. Journal of Geology,
Vol. 59, No. 6, I951, p. 614.

6. Baird, P. D., and Ward, W. H. Studies in glacier physics on the Penny Ice Cap, Baffin Island, I953. Part I: a description of the Penny Ice Cap, its accumulation and ablation. Fournal of Glaciology, Vol. 2, No. I 5 ,
r954, p. $34^{8}$.

7. Fristrup, B. Climate and glaciology of Peary Land, north Greenland. Union Géodésique et Géophysique Internationale, Association Internationale d'Hydrologie Scientifique, Assemblée générale de Bruxelles 1951, Tom. I, [1952],
p. 187-91. 8. Diamond, M. Precipitation trends in Greenland during the past thirty years. Fournal of Glaciology, Vol. 3 ,
No. 23, 1958, p. I77-80.

9. Bader, H. The significance of air bubbles in glacier ice. Journal of Glaciology, Vol. I, No. 8, 1950, p. $45^{\circ}$.

10. Arnold, K. C. Operation "Hazen"': survey 1957-r958. Ottawa, Defence Research Board, 1959, p. 71.

11. Hattersley-Smith, G., and Sagar, R. B. Glaciology. Operation "Hazen", norrative and preliminary reports, I957-58. Ottawa, Defence Research Board, I959, F. 27.

12. Hattersley-Smith, G. Glaciological research in northern Ellesmere Island. Canadian Geographer, No. 12, 1958, p. 34 .

13. Ahlmann, H. W. Glacier variations and climatic fluctuations. New York, American Geographical Society, I953,
p. 25 . 